\title{
Çin Halk Cumhuriyeti Eğitim Sistemi
}

\author{
DOI: 10.26466/opus.669104 \\ * \\ Bașak Coşkun ${ }^{*}-$ Mustafa Çelikten ${ }^{* *}$ \\ * Dr. Öğretmen, Sümer Fen Lisesi, Kocasinan/ Kayseri/ Türkiye \\ E-Posta: alasubisunt@gmail.com \\ ORCID: 0000-0002-0042-7130 \\ ** Prof., Dr, Erciyes Üniversitesi, Eğitim Fakültesi, Melikgazi / Kayseri / Türkiye \\ E-Posta: celikten@erciyes.edu.tr ORCID: $\quad \underline{\text { 0000-0001-7966-3912 }}$
}

\section{Öz}

Bu çalışmada dünyanın en kalabalık ülkesi, küresel ekonomide önemli söz sahibi ve Marksist-Leninist ideolojiye bağlı nadir ülkelerden biri olan Çin'in Eğitim Sistemini eyaletler ve bölgeler arası ortak özellikleriyle ele almak amaçlanmıştır. Çin Anayasası'nda eğitim vatandaşlar için hem hak hem de görev olarak görülmektedir. Çin'de eğitim merkez, eyalet, il, belediye ve ilçe düzeyinde kurulan teşkilatlarla yönetilmektedir. Çin'de zorunlu eğitim süresi altı yıl ilkokul ve üç yıl ortaokul/alt ortaöğretim biçiminde dokuz yildır. Ortaokuldan sonra girilen mecburi sınavla öğrencilerin gideceği lise belirlenir. Yükseköğretim kurumlarına kabuller lise bitirme sınav ve ulusal girişs sınavinda alınan sonuçlara bağlıdır. Üniversiteye girişte büyük rekabet yaşanır. Okullarda istihdam edilen "parti sekreteri" eğitim sisteminin komünist parti programına göre yürütüldüğünü yakından denetlemektedir. İki yıl veya dört ylllık lisans eğitimiyle öğretmen yetiştirilmekte, ancak atama öncesi adayları iki aşamalı bir sinava girmeleri gerekmektedir. Öğretmenlerin hizmetiçi eğitimine büyük önem verilmektedir ve kariyer basamakları bulunmaktadır. Bölgeye göre, öğretmen maaşları arasında büyük farklılıklar vardır. Eğitim yöneticisi yetiştirmede yeterlik, geliştirme ve ileri düzey adında üç basamakl program uygulanmaktadır. Eğitimin finansmanı merkez ve eyalet hükümetleri tarafından birlikte sağlanmaktadır. Öğretmen yetiştirmede hizmetiçi ĕ̆itime, yönetici yetiştirmeye ve meslek eğitimine verilen önem Çin Eğitim Sistemi'nin örnek alınabilecek yönleridir.

Anahtar Kelimeler: Çin, Eğitim Sistemi, Yapılanma, Süreç 


\title{
Education System in the People's Republic of China
}

$*$

\begin{abstract}
In this study, it is aimed to portray the education system in China, which is of great influence on global economy and one of the few Marxist-Leninist countries. In Chinese constitution, education is regarded both as a citizenship duty and right. In China education is governed by central, provincial, municipal, county departments of education. Mandatory education is nine years, with six years of primary and three years of middle school education. Students have to take a national exam to attend high school. For tertiary education students have to pass maturita (end of high school exam) and take Gao Kao- university entrance exam. There is a profound competition for university education. The schools in China is inspected closely by the "party secretary" employed in every school. The secretary follows all the programs and schools to make them obey communist party policies and rules. Teachers are trained in two or four year bachelor's programs, yet they have to take two exams before they can be appointed as teachers. The in-service training of teachers has great importance and teachers can have different professional titles according to their performances. There are big discrepancies in teacher salaries, depending on the region they work. In educational administrator's training, there is a three-stage training program as proficiency, development and advanced education. Education is funded together with central and provincial agencies. Chinese Education System has many implications, especially teacher and administrator training and vocational education models can provide good examples.
\end{abstract}

Keywords: China, Education System, Structure, Procedure. 


\section{Giriş}

Uluslararası rekabette, ülkelerin eğitim sistemlerinin anahtar rol oynadığını söylemek mümkündür. Küresel ekonomik pazarda pay sahibi olmak isteyen ülkelerin gün geçtikçe eğitime daha çok önem verdiği, değişimlere ayak uydurmak adına eğitim sistemlerini geliştirdikleri ve eğitime yaptıkları harcamaları arttırdıkları söylenebilir. Eğitim bir taraftan küresel taleplere cevap vermeye çalışırken bir taraftan da ülkelerin birlik ve bütünlügü için önemli roller oynamaktadır. Ülke dışından gelen taleplerin yarattı̆̆ı baskılara ve ülke içinde toplumun ihtiyaçlarına cevap vermeye çalışan eğitim sistemleri bu iki çekim arasında bir denge gözetilerek inşa edilmesi gerektiği söylenebilir.

Dünya'nun en büyük ekonomilerinden biri olan, Amerika gibi dev ekonomilerin tahtına göz diken Çin'in Eğitim Sistemi dikkat çekmektedir (Organization for Economic Cooperation and Development [OECD], 2016). Ekonomi alanındaki atılımları, uluslararası sınavlarda sergiledikleri performans gözlerin Çin Eğitim Sistemi'ne çevrilmesine sebep olmuştur (OECD, 2016). PISA gibi uluslararası sınavlarda üstün performans gösteren Şangay gibi eyaletlerin eğitim sistemleri farklı çalışmada incelenmiştir. Ancak bu çalışmada amaç bir eyalete odaklanmak değil, Çin Eğitim Sistemi ile ilgili genel bir çerçeve çizmektir. Bu yüzden, hem küresel ekonomide önemli söz sahibi, hem de Marksist-Leninist ideolojiye bağlı nadir ülkelerden biri olan Çin' in Eğitim Sistemi, eyaletler ve bölgeler arası ortak özellikleriyle ele alınmıştır.

\section{Çin'in Coğrafi, Siyasal, Sosyal ve Ekonomik Durumu}

Dünyanın en eski ve köklü medeniyetlerinden birine sahip olan Çin, sanat ve bilimde yüzylllar boyunca diğer medeniyetlere önderlik etmiştir, ancak 20. yüzyılın başlarındaki halk ayaklanmaları, kıtlıklar, askeri yenilgiler ve yabancı işgallerle başa çıkmaya çalışmıştır. 2. Dünya Savaşı'ndan sonra da, MAO Zedong'un önderliğinde otokratik bir sosyalist sistemle yönetildiği için 1980'lerin sonlarına kadar dışa kapalı kalmış bir ülkedir (Central Intelligence Agency [CIA], 2019). Resmi Adı Çin Halk Cumhuriyeti olan ülkenin başkenti Pekin'dir. Asya kıtasında bulunan ülke, doğuda Kuzey Kore, kuzeyde Moğolistan, kuzeydoğuda Rusya, kuzeybatıda Kazakistan, Kırgizistan ve Tacikistan, batı ve güneybatıda Afganistan, Pakistan, Hindistan, Nepal ve Butan, 
güneyde Burma, Laos ve Vietnam ile komşudur. Çin, 23 eyalet (province), beş özerk bölge ve dört merkezi yönetime bağlı belediye, iki özel yönetim bölgesine ayrılmıştır (China ABC, 2019). Kurulduğu 1949 yılından bu yana Çin, Çin Komünist Partisi (ÇKP) tarafından yönetilmektedir. ÇKP ülkenin tek siyasi hâkimidir. Partinin Genel Sekreteri aynı zamanda Devlet Başkanı'dır. Devlet yönetiminin en yetkili organı ÇKP'nin Merkez Komitesi'ne bağlı olan Polit Büro Daimi Komitesi'dir. Daimi Komite, Hükümetin de üzerinde bir kurum olup, ülkeyi ilgilendiren önemli konularda söz sahibidir. Yedi üyeden oluşan Komite'nin başkanı Devlet Başkanı Xi Jinping'dir ve komitenin üyeleri arasında başbakan da bulunmaktadır. Tüm üyeleri devlet lideri olarak kabul edilmektedir. Hükümet işlerini 28 üyeden oluşan ve Başbakan'ın liderliğinde Devlet Konseyi yürütmektedir dolayısıyla, Çin Halk Meclisi temsilidir ve yılda bir kez toplanır (www.mfa.gov.tr).

Yüzölçümü 9.6 milyon $\mathrm{km}^{2}$ olan ülkede 1.396 milyar insan yaşamaktadır (China ABC, 2019). Dünyanın en büyük yüzölçümüne sahip 4. ülkesi olan Çin, geniş bir alana yayıldığı için farklı coğrafi özelliklere ve iklim tiplerine sahiptir. Güney kesimlerinde muson iklimi hâkim olan Çin'de, özellikle kuzeybatı kesimleri sert kara ikliminin hüküm sürdügü bölgelerdir. Nüfusuyla da dünyanın en kalabalık ülkesidir (en.people.cn). Ailelerin tek çocuk sahibi olmaları teşvik edilmektedir. Yüksek nüfus, Çin için en büyük sorunlardan birisini teşkil etmenin yanı sıra, ülkenin ekonomik gücünün kaynağı niteliğindedir (The Economist Intelligence Unit, 2019). Nüfus içerisinde yaşlıların gençlere oranı giderek artmaktadır (World Bank, 2019). Ortalama yaşam süresi erkeklerde 73,09, kadınlarda 77,43, genel ortalama olarak ise 75,51 yıldır. Ülkede nüfusunun \%91,5'i Han kökenli Çinliler, \%1,3'ü Zhuang ve \%7,1'i diğer etnik kökenlerden oluşmaktadır (CIA, 2019). Toplamda 56 farklı etnik grup bir arada yaşamaktadır. Çeşitli tarihsel sebeplerden ötürü azınlıkların yaşadığı bölgeler, Han kökenli Çinlilerin yaşadığı bölgelerden daha az gelişmiştir. Devletin bu bölgeleri de eşit şekilde geliştirmek için 1980'lerden beri çeşitli önlemler aldığı belirtilmiştir (en.people.cn).

Standart Çince ya da Mandarin Çincesi adı verilen dil devletin resmi dilidir (CIA, 2019). Çince logografik bir dildir. Çin Alfabesi'nde 26 harf olmasına karşın, Çincede on binlerce farklı karakter (logo gramlar) vardır. İyi eğitim almış bir Çinli 6.000-8.000 karakter okuyabilir. Günlük bir gazeteyi okuyabilmek içinse ortalama olarak 2.000 ila 3.000 karakteri bilmek gerekmektedir 
(www.bbc.co.uk). Standart Çincenin yanı sıra, Guangxi'de Zuhang, Guangdong'da Yue, İç Moğolistan'da Moğol, Sincan Uygur' da Uygur ve Kırgız, Tibet'te Uygur ve Tibet dilleri resmi dil olarak tanınmaktadır. Devletin resmi dini 2010 yılında ateizm olarak ilan edilmiştir. Ancak, nüfusun \%18,2'si Budist, \%5,1'i Hıristiyan, \%1,8'i Müslüman'dır. \%21,9'u yerel dinlere inanmaktadır. Hindu ve Yahudi gibi diğer inanışlardaki insanlar da ülkede yaşamaktadir (CIA, 2019).

Çin dünyadaki en büyük 2. ekonomidir ve küresel ekonomide önemli rol oynamaktadır. Ancak hala gelişmekte olan ülkelerden biridir. Neredeyse 99 milyon insan fakirlik sınırının altında yaşamaktadır. Hindistan'dan sonra dünyadaki en büyük fakir nüfusuna sahip ülkedir ve fakirlik ülkedeki en önemli sorunlardan biri olmaya devam etmektedir (World Bank, 2019). Çin, maden ve mineraller yönünden zengin bir ülkedir. Aralarında demir, demir alaşımlı metal cevherleri, fosfat, tungsten, molibden ve titanyumun bulunduğu yaklaşık 17 maden ve mineral türünde dünya lideri konumunda bulunmaktadır. Bu arada Çin, uzay teknolojisi ve elektronik alanında kullanılan bazı ender bulunan madenlerin de artan orandaki üretici ve ihracatçısıdır. Yüzölçümü en geniş ülkelerden biri olarak, sahip olduğu hidroelektrik güç potansiyeli ve kömür rezervleri açısından da dünya birincisi ve önemli bir ham petrol ithalatçısıdır (Çin Halk Cumhuriyeti Ülke Raporu, 2013).

\section{Çin Eğitim Sistemi}

Dünyadaki en büyük ekonomilerden biri olmasına karşın diğer ülkelere nazaran Çin Eğitim Sistemi'yle ilgili çok az şey bilinmektedir (OECD, 2011). Bu eksikliği gidermek amacıyla hazırlanan bu çalışmada, Çin Eğitim Sistemi'nin politika ve amaçları, yönetim ve okul yapılanması, süreç boyutu bağlamında eğitim programları, eğitimin değerlendirilmesi, yönetici ve öğretmen yetiştirme, eğitim denetimi ve finansmanı konuları ele alınmıştır.

\section{Eğitim Politikası ve Amaçları}

Çin Halk Cumhuriyeti Anayasası'nın (2004) 19, 24, 36, 45 ve 46. maddeleri eğitimle ilgilidir. Anayasa'ya göre, eğitim almak vatandaşların hem görevi hem de hakkıdır (madde 46). Devlet tüm ulusun bilimsel ve kültürel seviye- 
sini arttırmak için sosyalist eğitim ve çalışmaların geliştirilmesinden sorumludur. Devletin çeşitli türlerde okul açma, zorunlu temel eğitimi yaygınlaştırma, ortaöğretim, mesleki eğitim, yükseköğretimi ve okul öncesi eğitimi geliştirme sorumlulukları vardır. Devlet, yasalara uygun şekilde çeşitli türlerde okul açma girişimlerini destekler (madde 19).

1995 tarihli Eğitim Kanunu, Çin Eğitim Sistemi'nin üzerine inşa edildiği temel kanundur. Bu kanunda da Anayasa'daki gibi, eğitim hem vatandaşlık görevi hem de hakkı olarak ifade edilmiştir (madde 9). Bu kanunla eğitim sisteminin ilke ve hedefleri ortaya konmuştur. Hem Çin Anayasa'sında hem de 1995 Eğitim Kanunu'nda yoğun bir biçimde sosyalist amaçlara hizmet etme vurgusu olduğu görülmektedir. Eğitimin sosyalist amaçlara hizmet etmesi gerektiği ile ilgili maddeler şunlardır: Sosyalist eğitimi geliştirmek için, devlet Marksizm-Leninizm, Mao Zedong Düşüncesi ve sosyalizmin Çin karakteriyle inşası teorilerini yol gösterici olarak korur ve Anayasa'nın temel ilkelerine uyar (madde 3). Devlet sosyalist modernleşmenin temeli olan eğitimin gelişmesine öncelikli önemi verir. Bütün toplum öğretmenlere sayg1 duyar (madde 4). Eğitim sosyalist modernleşmenin inşasına hizmet eder (madde 5). Devlet eğitim hizmetlerini vatanseverlik, kolektivizm ve sosyalizmin yanı sıra, idealler, etik değerler, disiplin, adalet, ulusal savunma ve etnik birlik değerleriyle sunar (madde 6).

Kanun'da ulusal değerlerin korunmasıyla ilgili ilkeler de mevcuttur. Örneğin, Eğitim Çin ulusunun tarihi ve kültürel geleneklerini sahiplenme ve yayma aynı zamanda insanlığın medenileşme sürecindeki başarılarını da benimseme ruhuyla yürütülür (madde 7). Bir başka ilke de laiklik ilkesidir; 8 . maddeye göre devlet eğitimi dinden ayırır. Herhangi bir kurum ya da kişi dini, devletin eğitim sistemini engelleyecek biçimde kullanamaz. Eşitliğe vurgu yapan maddeler de mevcuttur 9. maddeye göre, vatandaşların ırk, cinsiyet, din vb. ayrımı olmaksızın eğitim alma hakkı vardır. Devlet etnik azınlık gruplarına özelliklerine ve gerekliliklerine göre eğitim alma konusunda yardım eder (madde 10). Kanunda sosyalizm vurgusunun yanında, devletin dünyanın geri kalanından yalıtılmaması için de uluslararasılık gibi amaçlara da yer verilmiştir. Çin'de eğitimde eşitlik, sosyal eşitlik için elzemdir. Bütün vatandaşlara eğitime erişim hakkı ve kaliteli eğitim için firsat sağlamak sosyalist uyum içerisinde bir toplumun yaratılması için temel koşuldur (United Nations Educational Scientific and Cultural Organization [UNESCO], 2011). 
Okul öncesi eğitimin amacı yaşam boyu öğrenimin ve bireylerin bütüncül gelişiminin temellerini atmak olarak ifade edilmiştir. Temel ilke ise çocukmerkezliliktir. Dokuz yıllık zorunlu temel eğitimin amacı ise çocukların bütünsel gelişimi adına beş temel öğrenme deneyimini onlara sağlamak olarak belirtilmişti. Bu beş temel öğrenme deneyimi, ahlak ve vatandaşlık eğitimi, entelektüel gelişim, topluma hizmet, fiziksel ve estetik gelişme ve kariyerle ilgili deneyimler alanlarındadır (UNESCO, 2011).

\section{Eğitim Sisteminin Yapılanması}

Eğitim sisteminin yapılanması yönetim boyutuyla merkez, eyalet, belediye ve okul yönetimleri yapılanması çerçevesinde açıklanmıştır. Okul yapılanması ile okul öncesi eğitim, ilköğretim, ortaöğretim ve yükseköğretim konularının yanı sıra özel eğitim ve hayat boyu eğitim konularına da yer verilmiştir.

Yönetsel Yapılanma: Merkez, eyalet, il, belediye ve ilçe (county) düzeyinde eğitimin yönetiminden sorumlu yapılanmalar mevcuttur. Eğitim Kanunu'na (1995) göre, Devlet Konseyi ve halk hükümetleri bütün düzeylerde eğitim yönetimi ve rehberliğinden, Konsey bünyesindeki eğitim bölümleri ülke çapında eğitim yönetimiyle ilgili planlama, koordinasyon ve yönetiminden sorumludur (madde 14). Bu çerçevede ülkede eğitimle ilgili en üst organ Devlet Konseyi'dir. Devlet Konseyi'nden sonra Konsey'e bağlı olarak eğitim yönetiminden sorumlu birim Eğitim Bakanlığı'dır. Eğitim Bakanlığı eğitimle ilgili kanun ve yönetmelikleri, ilkeleri ve politikaları uygulama; eğitim politikaları oluşturma, eğitim geliştirme planları hazırlama ve koordine etme; ülkedeki eğitimle ilgili tüm birimler arasında koordinasyonu sağlama; eğitim sistemindeki reformlara rehberlik etme gibi sorumlulukları vardır. Okul öncesi eğitim yerel hükümetlerin sorumluluk ve yetki alanındadır. Zorunlu eğitim konusundaki rehberliği Devlet Konseyi sağlar ancak yürütülmesi ile ilgili sorumluluklar büyük oranda yerel hükümetlere verilmiştir. Benzer biçimde mesleki eğitimle ve yükseköğretimle ilgili yetki ve sorumluluklar Devlet Konseyi'nin denetiminde yerel idari birimlere verilmiştir (UNESCO, 2011).

Eğitim Bakanlı̆̆ı: Merkezi teşkilatta Eğitim Bakanı ile birlikte 6 müsteşar (Vice Minister of Education), 1 denetleme komisyonu başkanı, 2 müsteşar 
yardımcısı (Assistant of Minister of Education) görev yapmaktadır. Bakanlıkta 22 bölüm vardır. Bu bölümler Genel Büro, Politika ve Yönetmelikler, Geliştirme ve Planlama, Personel, Finans, Temel Eğitim I, Temel Eğitim II, Mesleki ve Yetişkin Eğitimi, Yükseköğretim, Etnik Azınlık Eğitimi, Öğretmen Yetiştirme, Beden, Sağlık ve Sanat Eğitimi, Ahlak Eğitimi, Sosyal Bilimler, Bilim ve Teknoloji, Kolej Öğrenci İşleri, Ulusal Üniversiteler, Lisansüstü Eğitim, Dil Öğretimi Planlama ve Yönetimi, Dil Bilgi Yönetimi, Uluslararası İşbirliği ve Değişim Bölümleri ve Ulusal Denetim Bürosudur (Ministry of Education of the People's Republic of China [MoE], 2019).

Bu birimler dışında eğitim politikaları oluşturulması ve uygulanmasında etkili olan birçok organ mevcuttur. Bunlardan bazıları, ulusal düzeyde uygulanan sınavları koordine eden ve denetleyen Ulusal Eğitim Sınavları Kurulu; eğitim programları geliştirmek ve değerlendirmek, eğitim materyalleri hazırlamak gibi görevleri olan Okul Eğitim Programı ve Kitap Geliştirme Ulusal Merkezi; vatandaşlara yükseköğretimde finansal destek sağlayan Çin Burs Konseyi; eğitimle ilgili araştırmaları destekleyen ve yayınlayan Çin Ulusal Eğitim Araştırmaları Enstitüsü'dür (UNESCO, 2011). Bu kurumlar Bakanlığa bağlıdırlar. Çin Eğitim Bakanlı̆̆ı sitesinde televizyondan eğitim yayınları yapmayı amaçlayan kurumlardan, öğretmen geliştirme ile ilgili oluşumlara 34 kurum listelenmiştir (MOE, 2019).

Eyalet Eğitim Bölümleri (Provincial Department of Education): Eyaletlerde kurulan bu bölümlerin ulusal eğitim politikalarını uygulamak, eyalet düzeyinde politikalar geliştirmek, eğitim araştırmaları yapmak, eğitim bütçesini yönetmek, denetim komisyonuna destek sağlamak gibi sorumlulukları vardır. Bu bölümlerde bir genel müdür (director-general), altı genel müdür yardımcisı (deputy director-general), bir eyalet parti eğitim komitesi sekreter yardımcısı (vice-secretary of provincial party education committee), bir eyalet eğitim disiplin çalışmaları komitesi sekreteri (secretary of provincial education discipline working committee) ve üç genel müfettiş yardımcısı (assistant inspector-general) görev yapmaktadır. Üst düzey yöneticiler dışında bölümde temel eğitim biriminden, eğitim denetimi bürosuna çeşitli amaçlara ve sorumluluklara sahip 15 birim eğitimle ilgili işleri yürütmektedir. Merkez teşkilata benzer biçimde eyalet düzeyinde de eğitimle ilgili ve oluşturulan politikalar üzerinde etkili olan çeşitli organlar vardır. Eğitim Araştırması Ensti- 
tüsü, Eğitim Yayınları Kurumu, Kredi ve Burs Merkezi oluşumlardan bazılarıdır (english.jsjyt.gov.cn). Eyaletlerde isimleri, sayıları ve kuruluş amaçları değişebilmektedir.

Belediye Eğitim Komisyonlan (Municipal Comission of Education): Çin'de iki tür belediyeden söz edilebilir. Bunlardan birincisi doğrudan merkez hükümete bağlı olarak yönetilen dört belediye, ikincisi ise eyalet yönetimine bağlı şehir belediyeleridir. Belediyelerde eğitimden sorumlu birim Belediye Eğitim Komisyonu'dur. Doğrudan merkeze bağlı olan belediyelerde bu birim Belediye hükümetine bağlı olarak çalışırken, şehir belediyelerindeki Belediye Eğitim Komisyonu Eyalet Eğitim Bölümü'ne bağlıdır. Komisyonun eğitimle ilgili yasa ve yönetmeliklerin uygulanması, eğitimle ilgili geliştirme planlarının oluşturulması, eğitimle ilgili merkez ve yerel birimler arasında koordinasyonun sağlanması, tüm okul düzeylerinde belli kalite standartları oluşturulması ve bunların denetlenmesi gibi sorumlulukları vardır. Birimin başında Eyalet Eğitim Komisyonu Genel Müdürü görev yapmaktadır (www.shanghai.gov.cn).

Şekil 1'de görüldüğü gibi Eyalet Eğitim Bölümü ile Belediye Eğitim Komisyonu (merkeze bağlı belediyeler) arasında hiyerarşik olarak denklik vardır.

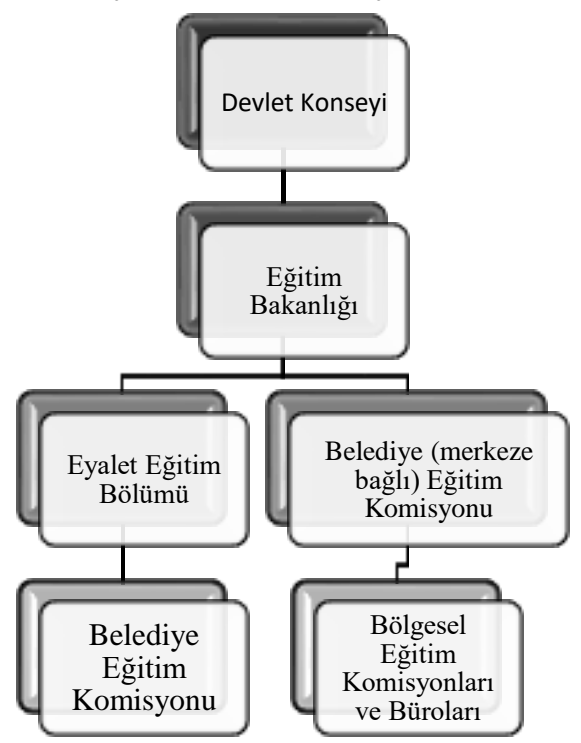

Şekil 1. Çin'de Eğitim Yönetimi Birimleri Arasındaki Hiyerarşi (Kaynak: Bakioğlu ve Özcan, 2014; MOE, 2019'dan uyarlanmıştır). 
Şekil 1'de görüldüğü gibi Eyalet Eğitim Bölümü ve merkeze bağlı Belediye Eğitim Komisyonları Eğitim Bakanlığı'na bağlıdır. Eyalet ve belediyelerde eğitimden sorumlu birimlerin bölgesel farklılıkları göz önünde bulundurarak eğitim programı hazırlamak ve öğretmen yetiştirme gibi sorumlulukları vardır. Ancak özellikle eğitim programıyla ilgili konularda Eğitim Bakanlığı'nın onayı gerekmektedir (Bakioğlu ve Özcan, 2014). Eyalet ve belediye eğitim komisyonları dışında ilçe ve bölgelerde eğitim büroları yönetim birileridir (english.jsjyt.gov.cn). Çin'de eğitim yönetimi yerelleştirilmiş gibi görünse de neredeyse tamamen merkeziyetçi bir anlayış hâkimdir. Yerel hükümetlere verilen yetkilerin kullanımı merkez hükümet tarafından sürekli bir biçimde takip edilmektedir (education.stateuniversity.com).

\section{Okul Yapilanmast}

Çin Eğitim Sistemi'nde genel olarak ilk dokuz yılı zorunlu olmak üzere eğitim süresi 6+3+3 şeklinde yapılandırılmıştır.

Okul Öncesi Eğitim: Uygulanan politikalar sebebiyle aileler tek çocuk sahibi olabildikleri için, çocuklardan akademik anlamda yüksek beklentiler erken çocukluk dönemi eğitimi düzeyinde başlamaktadır. 3-6 yaşlarındaki çocuklara sunulan okul öncesi eğitim kreşlerde ya da okul öncesi eğitim sınıflarında yapılmaktadır ve zorunlu değildir. Okul öncesi eğitim kurumları finans kaynağı açısından devlet kurumları ya da özel kurumlar şeklinde ikiye ayrılır. Devlete bağlı okul öncesi kurumları ise devlete, eyalete ve ilçe ya da kasabaya bağlı çalışabilirler. Nüfusun yarısından fazlasının yaşadığı kırsal bölgelerde okul öncesi eğitim sadece bir yıl süren ana sınıfı eğitiminden ibarettir. Özel kurumlar ise genellikle gelişmiş şehirlerde bulunmaktadır (Hu ve Szente, 2009).

Okul öncesi eğitim, örgün ve yaygın öğretim yaklaşımların birlikte kullanıldığı, toplulukla eğitimin zaman zaman aile eğitimiyle birleştiği birçok farklı şekilde sağlanmaktadır. Kırsal bölgelerde, genelde ana sınıflarında ya da dönemlik açılan kreşlerde okul öncesi eğitim yapılmaktadır. Daha uzak ve fakir bölgelerde ise dönemlik sınıflar, hafta sonu sınıfları, eğitim istasyonları, çocuk ziyaret günleri, evde eğitim dersleri ve diğer yaygın eğitim yaklaşım- 
larıyla okul öncesi eğitim alan çocuk sayısında artış yakalanmaya çalışılmaktadır (UNESCO, 2011). Çin Eğitim Sistemi okul yapılanması Şekil 2'de görülmektedir.

Şekil 2'de görüldüğü gibi örgün eğitimin temel bileşenleri zorunlu eğitim, genel ve mesleki alt ortaöğretim ve üst ortaöğretim, genel ve mesleki yükseköğretim kurumlarıdır. Yaygın eğitim biçimleri de Şekil 2'de gösterilmiştir. Illkokul ve Alt Ortaöğretim: Dokuz yıllık zorunlu eğitim ilkokulu ve alt ortaöğretimi kapsamaktadır. Birçok eyalette bu zorunlu dönem 6 yıllık ilkokul ve 3 yıllık alt ortaöğretim şeklinde planlanmıştır. Bazı eyaletlerde ise $5+4$ sistemi uygulanmaktadır. Alt ortaöğretim düzeyinde mesleki eğitim veren okullar vardır (UNESCO, 2011).

\begin{tabular}{|c|c|c|c|c|c|c|}
\hline Yas & $\begin{array}{l}\text { Okul } \\
\text { Yilı }\end{array}$ & & & & & \multirow{4}{*}{ 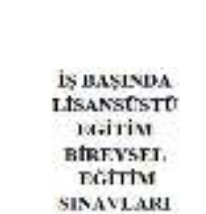 } \\
\hline 27 & 22 & \multirow{3}{*}{ DOKTORA } & & & & \\
\hline 26 & 21 & & & & & \\
\hline 25 & 20 & & & & & \\
\hline \multirow[t]{2}{*}{24} & 19 & \multirow{4}{*}{$\begin{array}{l}\text { YEKSEKK } \\
\text { LISANS }\end{array}$} & & & & \multirow{4}{*}{ 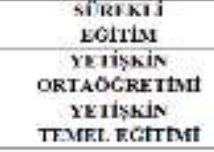 } \\
\hline & & & & & & \\
\hline 23 & 18 & & & & & \\
\hline 22 & 17 & & & & & \\
\hline 21 & 16 & \multirow{4}{*}{$\begin{array}{l}\text { LisANS } \\
\text { EGirimi }\end{array}$} & & & & \\
\hline 20 & 15 & & \multirow{3}{*}{\multicolumn{2}{|c|}{ YCKSEKOKUL }} & \multirow{3}{*}{$\begin{array}{l}\text { MESLEK } \\
\text { YUKKSEKOKULU }\end{array}$} & \\
\hline 19 & 14 & & & & & \\
\hline 18 & 13 & & & & & \\
\hline 17 & 12 & \multirow{3}{*}{\multicolumn{2}{|c|}{$\begin{array}{l}\text { GENEL UST } \\
\text { ORTAÖGRETIM }\end{array}$}} & \multirow{3}{*}{\multicolumn{2}{|c|}{$\begin{array}{l}\text { MESLEKI CST } \\
\text { ORTAŌGRETIM }\end{array}$}} & \\
\hline 16 & 11 & & & & & \\
\hline 15 & 10 & & & & & \\
\hline 14 & 9 & \multirow{3}{*}{\multicolumn{4}{|c|}{ GENEL ALT ORTAÖGRETIM }} & MESLEKI \\
\hline 13 & 8 & & & & & ALT \\
\hline 12 & 7 & & & & & ORTAÖGRETIM \\
\hline 11 & 6 & \multirow{6}{*}{\multicolumn{4}{|c|}{ ILKOKTL }} & \\
\hline 10 & 5 & & & & & \\
\hline 9 & 4 & & & & & \\
\hline 8 & 3 & & & & & \\
\hline 7 & 2 & & & & & \\
\hline 6 & 1 & & & & & \\
\hline 5 & & \multirow{3}{*}{\multicolumn{4}{|c|}{ OKUL ÖNCEST EGITIM }} & \\
\hline 4 & & & & & & \\
\hline 3 & & & & & & \\
\hline
\end{tabular}

Şekil 2. Çin Eğitim Sistemi Okul Yapılanması (Kaynak: UNESCO, 2011) 
1986'dan beri uygulanan Zorunlu Eğitim Yasası sayesinde ilkokul ve alt ortaöğretim düzeyinde okullaşma oranı \%99 üzerindedir (OECD, 2014).

Üst Ortaöğretim: Çin'de temel olarak üç tip üst ortaöğretim kurumu vardır. Bunlar, genel liseler, mesleki ve teknik eğitim veren liseler ve üst düzey başarı sergileyen öğrencilerin kaydoldukları "anahtar" liselerdir (Bakioğlu ve Özcan, 2014). Üst ortaöğretim genelde üç yıl sürmektedir (UNESCO, 2011). Mesleki ve teknik eğitim veren okulların bazılarında eğitim dört yıldır. Üst ortaöğretim düzeyinde okullaşma oranı \%87 civarındadır (OECD, 2014).

Yükseköğretim: Çin'de yükseköğretim düzeyinde eğitimi üniversiteler, araştırma enstitüleri, uzman enstitüler, bağımsız yüksekokullar, tıp fakülteleri ve kolejleri ve yetiştirme okulları sunulmaktadır. Lisans eğitimi genelde dört yıl sürer ancak tıp, geleneksel Çin tıbbı, mimarlık ve mühendislik alanlarında lisans eğitimi beş yıldır. İki ya da üç yıl eğitim veren programlar da mevcuttur. Lisansüstü eğitim iki ila üç yıl sürmektedir. Doktora eğitimi ise üç ila beş yllda verilmektedir (UNESCO, 2011).

Mesleki Ĕ̆itim: Çin'in hızlı ekonomik büyümesi sonucu eğitimli işgücüne ihtiyaç artmıştır. Bu yüzden mesleki eğitimde birçok reform gerçekleştirilmiştir ve Almanya' da uygulanan mesleki eğitim sistemi örnek alınmaya çalışılmıştır (Barabash, Huang ve Lawson, 2009). Çin'de mesleki eğitim alt ortaöğretim, üst ortaöğretim ve yükseköğretim düzeyinde olmak üzere üç seviyede verilmektedir. Dokuz yıllık zorunlu eğitimin bir parçası olan alt öğretim mesleki eğitimi temel mesleki bilgiye ve belli becerilere sahip işçi, köylü ve çalışan yetiştirmektedir. Bu okullar, genellikle ekonomik anlamda daha az gelişmiş kırsal bölgelere kurulmuştur. Eğitim üç ya da dört yıl sürebilmektedir. Üst ortaöğretim düzeyindeki mesleki eğitimin süresi iki ila dört yıl sürebilmektedir. Eğitimin uzunluğu okulun alt orta öğretimde mesleki eğitim almiş öğrencileri mi yoksa genel alt orta öğretimden gelen öğrencileri mi kabul ettiğine göre değişmektedir. Bu okulların mezunları üretim, hizmet, teknoloji ve yönetimde önemli pozisyonlarda çalışırlar. Ortaöğretim düzeyinde mesleki eğitim, uygulama becerilerine sahip işgücünü yetiştirmede önemli rol oynamaktadır (UNESCO, 2011). Üst ortaöğretime devam eden öğrencilerin \%50.4'ü mesleki eğitim veren bir ortaöğretim kurumunda eğitim almaktadır (OECD, 2014). Yükseköğretim düzeyinde mesleki eğitim veren kurumlara 
hem genel üst ortaöğretim mezunları hem de mesleki üst ortaöğretim kurumlarından mezun olanlar kabul edilmektedir. Mesleki eğitim kurumlarında sunulan eğitimin özellikleri endüstride ihtiyaç duyulan özelliklere göre şekillenmektedir. Mesleki eğitim sonunda diploma alan mezunların yeterlikleri ilgili kurumlar tarafindan kontrol edilir ve diplomalarına ek olarak mesleki yeterlik sertifikası ya da teknik sertifika alırlar (UNESCO, 2011).

Özel Eğitim: Çin'de engelli insan sayısı diğer ülkelere göre daha az görünmektedir bunun sebebi diğer ülkelerde engel olarak kabul edilen bazı vakaların Çin'de engel olarak tanımlanmamasıdır (Kritzer, 2011). Örneğin Amerika'da öğrenme güçlüğü bir engel olarak kabul edilirken Çin'de engel olarak kabul edilmemektedir (Annual Disability Statistics Compendium, 2009; Akt. Kritzer, 2011). Engelli bireylerin eğitimi özel eğitim okullarında ya da genel eğitim veren okullarda yapılmaktadır. Özel eğitim okulları genelde büyük şehir merkezlerinde bulunmaktadır. Çin'de nüfusun büyük bir kısmı kırsal kesimde yaşamaktadır, dolayısıyla bu bölgelerde yaşayan çocular için özel eğitim veren okullara gidebilmek imkanı oldukça sınırlıdır (Kritzer, 2011).

Zorunlu Eğitim Kanunu ve 1990'lardan beri kaynaştırma eğitiminin de yaygınlaşmasıyla Çin'de engelli öğrencilerin eğitime oranı artmıştır. Engelli öğrencilerin çoğu genel eğitim sınıflarında öğrenim görmektedir. Bu sınıflarda eğitim alan engelli öğrenciler görme, işitme engelli ya da hafif düzeyde zihinsel engellilerdir. Ancak bu öğrencilerin eğitimleriyle ilgili uygulamalar oldukça tutarsızlık göstermektedir. Sınıflar oldukça kalabalık olduğu için, bu öğrenciler çoğu zaman ihmal edilmektedirler. Ayrıca öğretmenlerin de bu alanda yeterli eğitimleri yoktur. Bireyselleştirilmiş eğitim programı, sınırlandırılmamış çevre ve aile katılımı gibi kaynaştırma eğitiminde bulunması gereken unsurlar ihmal edilmektedir. İleri düzeyde ya da çoklu engeli olan bireyler genel eğitim sınıflarına kabul edilmemektedir. Özel eğitim okullarında bir sınıfta ortalama olarak 10 öğrenci eğitim görmektedir. Ancak özel eğitim okulları belli başlı gelişmiş bölgelerde bulunmaktadır (Kritzer, 2011). Bu bilgiler ışı̆̆ında kırsal bölgelerde yaşayan ve ileri düzeyde ya da çoklu engeli olan bireylerin hemen hiç eğitim almadıklarını söylemek mümkündür. 
Hayat Boyu Öğrenme: Dışardan bakıldığında Çin'in nüfusu başlı başına bir sorun gibi görünmektedir. Bu kadar insanı beslemek dahi büyük bir iştir. Ancak bu büyük nüfus ülkenin ekonomik gelişmesi için anahtar rolü oynamaktadır. Efsanevi lider Mao da "bir elin nesi var iki elin sesi var" (many hands make light work) diyerek yüksek nüfusun bir avantaj olduğuna işaret etmiştir. Hayat boyu öğrenme de bu anlayış ışığında şekillendirilmiştir ve Çin'de ekonomik gelişme için bu büyük nufüsün sürekli eğitilmesi gerektiği düşünülmektedir (Wang ve Parker, 2014).

Çin'de hayat boyu öğrenme hizmetleri oldukça farklı kurumlar tarafından sağlanmaktadır. Bu açıdan parçalanmış bir durum söz konusudur. Hayat boyu öğrenme hizmetlerini veren birimlerin büyük kısmı Çalışma ve Sosyal Güvenlik Bakanlığı'na bağlıdır. Ancak Personel Bakanlığı, Geliştirme ve Reform Komisyonu gibi başka birçok bakanlık ve kurum hayat boyu öğrenme etkinlikleri düzenlemektedir. Özel kurumlar da pazar ekonomisinin gereklerine cevap verecek şekilde ve çalışan arz-talep arasındaki uyumsuzlukları kapatmak amacıyla verdikleri hizmetiçi eğitim programlarıyla hayat boyu öğrenmeye katkıda bulunurlar. Bunun yanı sıra sivil toplum örgütleri de hayat boyu öğrenmede pay sahibidir (Dahlman, Zhihua Zheng ve Wang, 2007).

Çin Ulusal İstatistik Bürosu 2013 verilerine göre ülkede 80.797 ortaöğretim kurumu vardır. Bunların 54.572'si alt ortaöğretim kurumudur. Bu kurumlarda 5.988.381'i öğretmen olmak üzere toplam 7.569.100 personel çalışmaktadır. İlkokul sayısı ise $235.369^{\prime}$ dur ve bu kurumlarda 5.538.480'i öğretmen olmak üzere 5.607.283 personel çalışmaktadır. 1.933 özel eğitime muhtaç bireylere eğitim veren özel eğitim kurumu ve 198.553 okul öncesi eğitim kurumu faaliyet göstermektedir. Özel eğitim kurumlarında çalışan öğretmen sayısı 45.653, okul öncesi eğitim kurumlarında çalışan öğretmen sayısı ise 1.663 .487 'dir. 2013 yılında ortaöğretim kurumlarında öğrenim gören öğrenci sayısı 44.883.526's1 alt ortaöğretim öğrencisi olmak üzere 88.582.754'tür. İlkokula devam eden öğrenci sayısı 94.848 .050 ve okul öncesi kurumlardaki öğrenci sayısı 38.946.903'tür. Özel öğretim kurumlarında ise 368.103 öğrenci kayıtlıdır (www.stats.gov.cn). Sınıflarda ortalama öğrenci sayısı 37.1'dir. Bu oran öğrenci sayısının 21 olduğu OECD ortalamasının oldukça üzerindedir. Bölgeler ve okullarda ortalama öğrenci sayısı 17 ila 54 arasında değişebilir (OECD, 2014). 2014 verilerine göre Çin'de ortaöğretimden mezun olmuş öğrencilerin devam edebildiği (regular 
colleges and universities) toplam 2279 yükseköğretim kurumu, yetişkinlerin eğitim alabildikleri (colleges and universities for adults) 329 yükseköğretim kurumu bulunmaktadır (MoE, 2015). 25-64 yaş arasında Çin vatandaşlarının $\% 5$ 'inden daha azı yükseköğretim diplomasına sahiptir. Bu oran \%30 olan OECD ortalamasının oldukça altındadır (OECD, 2014).

\section{Ĕ̆itim Sistemi'nin Süreç Boyutu}

Çin'de zorunlu eğitime başlama yaşı altıdır. Bazı bölgelerde yedi yaşına kadar ertelenebilir (Bakioğlu ve Özcan, 2014). İlköğretim ve ortaöğretimde akademik yıl iki döneme ayrılmıştır. 1. Dönem eylülde ikinci dönem ise genelde mart ayında başlar. Bir okul yılı 36 haftalık ders dönemi, iki ya da üç haftalık genel değerlendirme ve sinav dönemini kapsar (UNESCO, 2011). Zorunlu eğitim boyunca öğrenciler her dönemin sonunda bitirme veya kontrol sinavına girerler (Bakioğlu ve Özcan, 2014). Kış ve yaz tatilleri genelde 11 haftadır. Yükseköğretim kurumlarının birçoğunda ise akademik yıl üç döneme ayrılmıştır. Zorunlu eğitim süresinde ders uzunluğu, haftalık ders saati gibi konuları eyaletler düzenlemektedir. Etnik azınlık gruplarının kendi dillerini kullanma ve geliştirme konusunda haklarını korumak için devlet bazı okullarda iki dille eğitim uygulamasına gitmiştir. Bazı okullarda üç dille öğretim de yapılmaktadır (UNESCO, 2011).

Dokuz yıllık zorunlu eğitimden sonra Çin'de öğrenciler üst ortaöğretime devam edebilmek için giriş sınavına girerler. Bu sınavın ismi "Zhongkao"dur. Ne türde üst orta öğretim kurumu olursa olsun, eğitime devam etmek isteyen herkes bu sinava girmek zorundadır. Her yıl haziran sonu ya da temmuz başında yapılan sınavlar Eyalet Eğitim Bölümü tarafından düzenlenir. Gerçek sınavdan önce tüm eyalet çapında iki kez deneme sınavı düzenlenmektedir. Sınav sonucuna göre öğrencinin ne tür bir üst ortaöğretim kurumuna (yüksek lise, genel lise ya da meslek lisesi) gideceği belirlenir. Bazı eyaletlerde alt ortaöğretim mezunu olabilmek için de bu sinavda başarılı olma şartı aranmaktadır. Başarılı olamayan öğrencilerin belgeleri alt ortaöğretim kurumuna geri gönderilir. Sınavdan geçemediği için alt ortaöğretim diploması alamayan öğrencilere bazı eyaletlerde telafi sınavları yapılmaktadır. Sınav soruları Çince, matematik, İngilizce, fizik, tarih, politika, kimya ve beden eğitimi derslerini kapsamaktadır. Sınavın uygulanma biçimi eyaletlerde değişebilmektedir. Örneğin Çince konuşulmayan bölgelerde (Sincan 
Uygur Özerk Bölgesi gibi) Çince sorularında açık kitap uygulaması yürütülmektedir (www.chinaeducation.info).

Üst ortaöğretim kurumlarında kredili sistem uygulanmaktadır. Mezun olabilmek için öğrencilerin 116'sı zorunlu 28'i seçmeli derslerden olmak üzere 144 krediyi tamamlamaları gereklidir. Kredi tamamlamak mezun olmak için bir koşuldur ancak yeterli değildir. Krediyi tamamlayan öğrenciler eyaletlerin düzenlediği "genel yetenek testi" ne girerler ve başarılı olanlar üst ortaöğretim diploması almaya hak kazanırlar. Bu sınavda dokuz temel alandan sorular sorulmaktadır. Bu temel alanlar politika, Çince, matematik, yabancı dil (genelde İngilizce ancak Japonca, Rusça, Fransızca ya da Almanca da olabilir), fizik, kimya, biyoloji, tarih ve coğrafyadır. Bu sınav yılda iki kez yapılmaktadır. Öğrencilerin üst ortaöğretimin ikinci yılından itibaren sınavlara girme hakları vardır. Elde edilen en yüksek puan geçerli sayılır (UNESCO, 2011).

Yükseköğretim kurumlarına kabuller lise bitirme sınavı ve ulusal giriş sınavında alınan sonuçlara bağlıdır. Üniversiteye girişte büyük rekabet yaşanır. En yüksek puanın 500 olduğu sınav sisteminde öğretmen yetiştiren bir yükseköğretim kurumuna girmek için 280-370 arasında bir puan almak gereklidir (Bakioğlu ve Özcan, 2014). Yükseköğretim kurumlarına girebilmek için öğrencilerin girmeleri gereken sınavın adı “Gao Kao"dur. İki ila üç gün süren bu sınav yerel eğitim birimlerinin belirlediği tarihlerde yapılır. Sınavın uygulamasından da yerel birimler sorumludur. Öğrencilerin başarılı olmaları gereken sınav konuları öğrencilerin almak istediği lisans eğitimi alanına göre değişmektedir. Sınavı geçemeyen öğrenciler genellikle bir yıl daha hazırlanırlar. Tüm öğrencilerin almak zorunda olduğu testler matematik, İngilizce ve Çince testleridir. 2014 yılında 9.390 .000 öğrenci bu sınava girmiştir (www.chinaeducenter.com).

Çin'de yükseköğretim sisteminde önemli reformlar yapılmaktadır. Bu reformlarla üniversitelere daha fazla özerklik vermek amaçlanmaktadır. Farklı finans kaynakları olan üniversitelerin kurulması teşvik edilmektedir. "Proje 211" çalışmasıyla Çin'deki 100 büyük üniversite ve çeşitli bölümler dünyadaki en iyi üniversite ve bölümler arasına sokmak amaçlanmaktadır. Bu projeyle akademisyenlerin en az iki yıl yurtdışında çalışmaları yükümlülüğü getirilmiş, yılda yapmaları gereken bilimsel yayın sayısına çeşitli standartlar getirilmiştir (Bakioğlu ve Özcan, 2014). Devlet Lisansüstü eğitime girişlerde de 
sınav uygulanmaktadır. Sınav başarılı olanlar lisansüstü eğitime başvurabilirler. Doktoraya kabul edilmek içinse yüksek lisans diplomasına sahip olmak, doktoraya giriş sınavında başarılı olmak ve en az iki referans mektubu gerekmektedir (UNESCO, 2011)

Çin'de okullarda eğitim Devlet Konseyi tarafından çok yakından parti sekreterleri aracılığıyla takip edilmektedir. Çin okullarının yönetiminde okul müdürü okulun genel idaresinden sorumludur. Yetki ve sorumluluklarını müdür yardımcıları ve bölüm başkanlarıyla paylaşır (Bakioğlu ve Özcan, 2014). Okul yönetimi yapılanması Şekil 3'te verilmiştir.

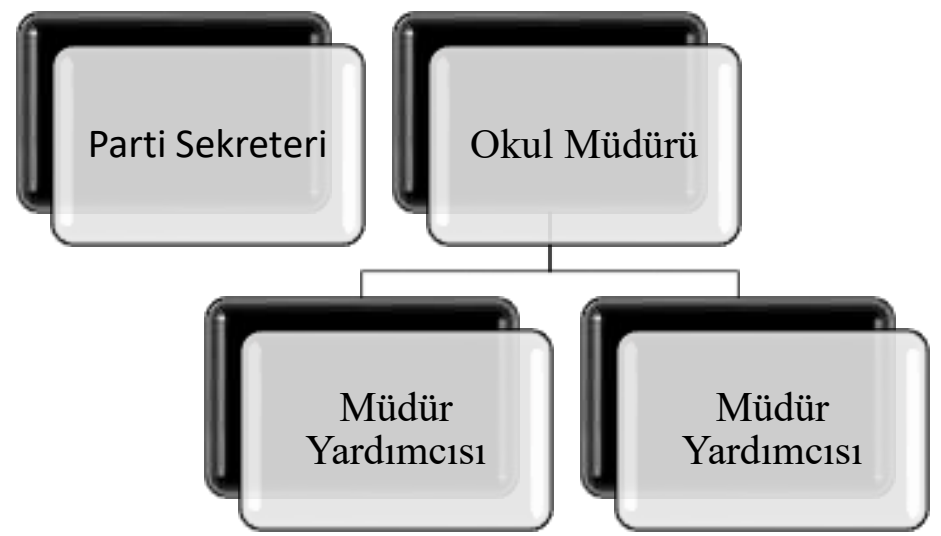

Şekil 3. Çin Ĕ̆itim Sistemi'nde Okul Yönetimi Yapılanması (Kaynak: Bakioğlu ve Özcan, 2014'ten uyarlanmıştır.)

Şekil 3'te görüldüğü gibi parti sekreterleri de okul yönetiminde görevlendirilmektedir. Bu kişiler ülke yönetimince belirlenir ve atanır. Görevleri okul yönetimini, dersleri, kitapları ulusal eğitim politikaları doğrultusunda yönlendirmektir (Bakioğlu ve Özcan, 2014). 1980'lere kadar okul müdürü parti sekreteri görevi de yapmıştır. 80'ler sonrasında okul müdürü dışında atama yoluyla görevlendirilen parti sekreterleri okullarda sosyalist eğitim amaçlarına hizmet edilmesi konusunda müdürün sağ kolu olmuştur (Johnson, Møller, Jacobson ve Wong, 2008).

Eğitim Programları: Çin'de eğitim programları eğitimin amaçlarına uygun bir biçimde sosyalist modernleşmenin gereklerine cevap verecek biçimde düzenlenmiştir. Eğitim programları 1992, 1998 ve 2001 yıllarında büyük oranda değiştirilmiştir. 1992 yılında derslerin birbirinden bağımsız 
bir biçimde öğretilmesini engelleyecek yeni yapılandırmalara gidilmiştir. Ayrıca eğitim programlarına daha fazla seçmeli ders eklenmiş, bilim ve sanat dersleri arasında bir denge yakalamak amaçlanmıştır. 1998 yılında yapılan değişiklerle ise ders içerikleri kolaylaştırılmıştır. 2001 yılında öğretme ve değerlendirme yöntemlerinde yapılan değişikliklerle de niteliği yüksek eğitim yöntemlerine geçmek amaçlanmıştır. Yapılan bu değişikliklerin oldukça yavaş dağıldığı ve kabul edildiği görülmektedir (UNESCO, 2011).

Zorunlu eğitim dönemi ve üst ortaöğretim için hazırlanan eğitim programları eğitim politikalarına ve amaçlarına hizmet edecek biçimde yapılandırılmıştır. Eğitim Programı Geliştirme Konseyi'ne göre zorunlu eğitim programıla öğrencilere (UNESCO, 2011);

1. Ailede, toplumda, ulusta rollerini ve sorumluluklarını bilmek ve insanların iyi oluşlarına ilgi göstermek,

2. Ulusal kimliği kavramak, ulusun ve topluma katkıda bulunmaya adanmak,

3. Bağımsız okuma alışkanlığı geliştirmek,

4. İngilizce ve Çince konuşmalara aktif ve güven duyarak katılmak,

5. Yaratıcı düşünce ve bağımsız öğrenme becerileri geliştirmek

6. Sekiz anahtar öğrenme alanında temel ve geniş bilgiye sahip olmak

7. Sağlıklı bir hayat biçimi sürmek ve estetik ve fiziksel etkinlikler için ilgi geliştirmek gibi yeterlik ve becerileri kazandırmak amaçlanmaktadır. Üst ortaöğretim eğitim programıla özetle öğrencilerin bütüncül bir biçimde gelişmeleri, öğrencilerin potansiyelini ve öğrenmeyi öğrenme becerilerini geliştirmek amaçlanmaktadır. Eyaletler yeni eğitim programlarını aynı anda uygulamaya başlamamışlar, imkânları dâhilinde aşamalı bir biçimde geçiş yapmaktadırlar. Eyaletlerin eğitim programlarını düzenleme, seçmeli dersleri belirleme yetkileri olsa da, Eğitim Bakanlığı'nın belirlediği sınırların dışına çıkamazlar. (UNESCO, 2011).

Eğitim Denetimi: Çin'de eğitim denetiminin Devlet Konseyi tarafından sürekli bir biçimde sosyalist amaçlara uygun bir biçimde yapıldığı söylenebilir. Devlet Konseyi doğrudan denetleme yapmasa da eğitim yönetiminde hemen 
her birimde var olan parti sekreterleri sosyalist yönetimin sürekli denetiminin bir göstergesi sayılabilir. Çin'de doğrudan eğitim denetimi yapma görevi olan ulusal düzeyde kurum Devlet Eğitim Denetimi Birimi'dir. Bu birimde bir baş denetmen, bir baş denetmen yardımcısı ve eyalet ve belediye eğitim bölümlerini temsilen 60 denetmen görev yapmaktadır. Yerel yönetimler düzeyinde de benzer birimler kurulmuştur. Tüm düzeylerde kurulmuş olan denetim birimlerinin görevleri kanunların, yönetmeliklerin, ilkelerin ve politikaların eğitim kurumlarında uygulanıp uygulanmadığını takip etmektir. Yerel düzeydeki birimlerin görevleri okulların eğitimini değerlendirmek ve okullara rehberlik sağlamak ve gerektiğinde hükümete bu konularda rapor sunmayı da kapsamaktadır (UNESCO, 2011).

Çin'de denetim sisteminin temel aktörü müfettişlerdir. Müfettişlerin işe alım sürecinde genel yetenek ve genel kültür sınavlarının yanında mesleki alan bilgisi sınavları yapılır. İşe alınan müfettişler iki yıl müfettiş yardımcısı olarak görev yaparlar. Belli dönemlerde okullara rehberlik yapmak için okulları ziyaret eden müfettişler öğretmenleri hizmet içi eğitime yönlendirebilirler. Müfettişin yönlendirdiği hizmet içi eğitim katılmak ve sonunda bir rapor hazırlamak öğretmenler için zorunluluktur. Öğretmenlerin ödüllendirilmesi ve cezalandırılması da yetki alanlarına girmektedir (Rong ve Shı, 2001; MOE, 2019, Akt. Bakioğlu ve Özcan, 2014). Okulların öz denetimlerini de yapmaları istenmektedir, öz denetim sürecine okul yönetimi, öğrenciler, veliler ve diğer paydaşlar katılmaktadır. Eğitimde kaliteyi yükseltmek adına hem iç hem de dış denetim yoğun bir biçimde yapılmaktadır (UNESCO, 2011).

Öğretmen Yetiştirme: Öğretmen yetiştirme alanında ulusal düzeyde rehberliği Devlet Eğitim Komisyonu sağlamaktadır. Eyalet, özerk bölge ve belediyeler öğretmenlerin hizmet öncesi ve hizmet içi eğitimlerinin yürütülmesinden ve ilgili kurumlarla işbirliği yapılmasından sorumludurlar (UNESCO, 2011). Çin'de öğretmenlik yapabilmek için üç tür okulda eğitim alınabilir. Bunlar öğretmen yetiştiren üst eğitim kurumları, iki yıllık kolejler ve dört yıllık eğitim üniversiteleridir. Öğretmen yetiştiren bu kurumların mezunları öğretmenlik yapabilmek için sertifika almak zorundadırlar. Bu sertifika iki aşamada alınmaktadır. Bu aşamalardan ilki Ulusal Mandarin Dili Testi'nde başarılı olmaktır. Bu sınav sonrasında adaylar pedagoji, psikoloji, öğretim yöntemleri ve becerileri konusunda bir sınava daha girmektedirler. Öğretim becerilerini sergilemek için, sınavın bir parçası olarak, adayların bir örnek ders 
yapmaları istenmektedir. Lisans diplomasına sahip olanlar ikinci aşamadan muaf tutulmaktadırlar çünkü bu becerileri üniversite eğitimiyle edindikleri varsayılmaktadır. Sınavlarda başarılı olan üst ortaöğretimden mezunları okulöncesi eğitim kurumları ve ilkokullarda, kolej mezunları alt ortaöğretim kurumlarında ve lisans eğitimi almış olanlar üst ortaöğretim kurumlarında istihdam edilmektedirler (www.ncee.org). Üniversitelerde okul öncesi öğretmenliği programları olsa da buradan yetişen öğretmenler genellikle üst ortaöğretim düzeyinde okul öncesi eğitimi derslerinde öğretmenlik yapmak için istihdam edilmektedirler (Hu ve Szente, 2009).

Öğretmenlerin hizmet öncesi eğitiminde eyaletler arası farklılıklar da mevcuttur. Örneğin Şangay' da ilkokul öğretmenlerinin de en az iki yıllık kolej mezunu olmaları talep edilmektedir (www.ncee.org; Bakioğlu ve Özcan, 2014).

Öğretmenlerin hizmet öncesi eğitimlerinin yetersiz olduğu söylenebilir. Bu yüzden de hizmet içi eğitime çok önem verilmektedir ve bu konuda birçok düzenleme mevcuttur. Okullar öğretmenlerin yetiştirilmesi için başlıca yerdir. Göreve başladıktan sonra öğretmenlerin sistematik ve sürekli bir biçimde hizmet içi eğitim almaları gerekmektedir. Öğretmenlerin lisans, yüksek lisans ya da doktora derecesini almaları teşvik edilmektedir (UNESCO, 2011). Yeni göreve başlayan bir öğretmen genellikle üç yıl bir mentörle çalışır. Öğretmenlerin kendilerini sürekli geliştirmeleri beklenmektedir. Bunun için diğer öğretmenlerin derslerini izlemeyebilir, haftalık tartışma gruplarında öğretim sorunlarını ve iyi uygulamaları tartışmalarına katılabilir, bilimsel yayın yapabilirler. Bunlar, Çin'de çalışan bir öğretmenin kendini geliştirmek için yapabileceği rutinleşmiş etkinliklerdir (www.ncee.org).

Çin'de öğretmenler çok çeşitli unvanlar alabilmektedirler. Bu unvanlar usta öğretmen, birinci düzey, ikinci düzey ve üçüncü düzey öğretmen unvanlarına sahip olabilirler. Bu unvanlar öğretmenlerin kıdemlerine ve sergiledikleri performansa göre verilmektedir. Örneğin birinci düzey öğretmen olmak için hem okul içinde hem de bölgeden gelen müfettişlerin değerlendirmelerini başarıyla geçmek gerekmektedir. Usta öğretmenler liderlik özellikleri de sergileyen sıra dışı öğretmenlerdir. Genellikle sıra dışı bir performansla yıllardır öğretmenlik yapan öğretmenler bu unvanı alabilirler. Bu unvanı almak büyük bir onurdur. Örneğin Şangay'da öğretmenlerin sadece 
\%0,1'i usta öğretmen unvanına sahiptir (www.ncee.org). Mesleki eğitim kurumlarında uygulama rehber öğretmeni gibi daha farklı ve çeşitli unvanlarla öğretmenler sınıflandırılmışlardır (UNESCO, 2011).

Merkez Hükümet' in belirlediği çerçeveye uygun olarak okullar öğretmenlerini kendileri seçerler. Ancak çeşitli düzeylerde ve türde okulların alacağı öğretmen sayısını Hükümet belirler. Okulların öğretmenlerin sistematik, sürekli ve etkili bir biçimde yetiştirilmesi için yeterince zaman ve materyal sağlamaları gerekmektedir. Öğretmenlerin maaşları devlet memurlarından daha az ya da daha yüksek olamaz. Ancak maaşlarını \%30'u oranında çeşitli teşvikler almaktadırlar. Bu teşvikler performans ve kıdem gibi çeşitli unsurlara göre değişmektedir. Net bir rakam söylemek mümkün değildir çünkü Şangay gibi eyaletlerde öğretmenlik mesleği oldukça prestijli ve yüksek kazanç sağlayan bir işken, kırsal kesimlerde düşük öğretmen maaşları bağışlarla zar zor ödenebilmektedir (www.ncee.org; UNESCO, 2011).

Yönetici Yetiştirme: Çin'de öğretmenlerin okul müdürlüğü için uzun yıllar öğretmenlik yapmış olmaları ve başarılı bir öğretmenlik kariyerine sahip olmaları gereklidir. Eğitimdeki diğer yönetsel kademelerde de hemen herkes öğretmen olarak göreve başlamıştır (www.ncee.org). 1980'lerin sonuna kadar yönetici yetiştirme usta-çırak anlayışıyla yapılmıştır. Ancak sonrasında deneyimle eğitimin bütünleştirildiği bir anlayışla okul yöneticileri yetiştirilmiştir. Eyalet, belediye ve bölge düzeylerinde açılan yönetici yetiştirme kurumları Eğitim Bakanlığı'nın rehberliğinde çalışmaktadır. 1999 yılında kurulan Pekin Normal Üniversitesi (normal üniversite öğretmen yetiştirme amaciyla kurulmuş üniversitelere verilen isimdir) ve Doğu Çin Normal Üniversitesi birincisi ilköğretim müdürleri ikincisi ortaöğretim müdürleri yetiştirme konusunda koordinasyon sağlayan merkezlerdir. Bu üniversiteler yerel yönetim birimlerine bağlı olarak faaliyet gösteren yönetici yetiştirme kurumlarının oluşturduğu ağın merkezidir. Yönetici yetiştirme programındaki eğitmenler yönetim, psikoloji ve eğitim fakültelerinden araştırmacilar ve akademisyenlerdir. Çin'de okul yöneticilerine verilen üç tip eğitim vardır (Yan ve Ehrich, 2009): Yeterlik eğitiminde asgari 300 saat süren bu program göreve yeni başlayan yöneticilere sunulmaktadır. Eğitim sonunda sertifika alabilmek için okul müdürleri tez çalışmasına benzer yazılı bir çalışma sunmak zorundadırlar. Geliştirme eğitimi yöneticiliğin ilk beş yılında yeterlik eğitimi sertifikası alabil- 
miş müdürlere verilmektedir. İleri düzeyde eğitim sıra dışı bir yönetim performansı sergilediği için seçilen müdürlere verilen bu eğitimde kıdem şartı aranmamaktadır. Eğitim süresince okul müdürleri eğitimin verildiği kampüste bir ay yaşarlar ve bu süreçte tartışmalara ve derslere katılırlar, eğitim aldıkları bölgedeki okulları ziyaret ederler. Eğitim sonunda bu bir aylık öğrenme deneyimini anlatan yazı hazırlamaları istenmektedir.

Eğitimin Finansmant: Huang, McCarty ve Tausun'a (2010) göre 1980'lerde Çin Eğitim Sistemi'nin finansmanı büyük ölçüde merkezilikten uzaklaştırılmıştır. İlçe ve kasaba düzeyindeki eğitim birimlerine zorunlu eğitimin finansmanı konusunda büyük sorumluluklar verilmiştir. Eğitim finansmanı ile ilgili sorumlulukların yerel yönetimlere devredilmesiyle devlet yerel hükümetlerin, toplumun, bireylerin ve toplumsal aktörlerin eğitimde rol üstlenebilmelerini sağlamıştır. Bu stratejiyle temel eğitime erişim konusunda büyük ilerlemeler kaydedilmiştir. Ancak bu durum bölgelerde büyük eşitsizliklere sebep olmuştur. Bazı bölgelerde eğitim için vergi dışında bazı kesintiler yapma yoluna gidilmiştir. Bazılarında ise ailelerden okul ücreti talep edilmiştir. Yetki ve sorumluluklar konusunda yönetim birimleri arasında net ayrımlar yapılmaması sorunlara neden olmuştur. Bazı bölgeler finanslar kaynakları sınırlılıkları yüzünden öğretmen maaşlarını dahi ödeyemez hale gelmişlerdir (www.ncee.org). Bu sorunları çözmek için hükümet yeniden merkezileşme reformuna gitmiştir. Özellikle zorunlu eğitim için yapılan harcamalara merkez ve eyalet düzeyinde de kaynak sağlanmaya başlamıştır (Huan, McCarty ve Tausun, 2010).

Günümüzde zorunlu eğitimin finansmanına merkez ve eyalet hükümetlerinin katkısı vardır ancak belediye ve bölge yönetimleri finansmanda hala anahtar rol oynamaktadır. Yükseköğretimin finansmanında ise büyük ölçüde merkez ve eyalet hükümetleri sorumludur. Mesleki eğitim ve yetişkin eğitiminde ise sanayi kuruluşları ve kamu kurumları gün geçtikçe daha önemli hale gelmektedirler (Ling ve $\mathrm{Wu}, 2008$ ). Çin'de 2012 yılında GSMH'nin \%4, 28'i eğitime harcanmıştır (www.stats.gov.cn). 1986 Zorunlu Eğitim Kanunu'na göre zorunlu eğitim ücretsizdir (madde 2). Ancak uygulamada durum böyle değildir. Kırsal kesimde yaşayan aileler gelirlerinin neredeyse yarısını çocuklarının eğitimine harcamaktadırlar. Bu tutar yıllık ortalama 2000 Çin yuanıdır. 130 kişiye varan sınıflarda çocuklarını öğretmenin masasına yakın bir sıraya oturmak için aylık 300 yuan ödeyen aileler vardır 
(Roberts, 2013). Ülkede eğitimin merkez, eyalet ve yerel yönetimlerce, sosyal kurumlar, ticari kuruluşlar ve ailelerin katkısıyla sağlandığını söylemek mümkündür.

\section{Sonuç ve Öneriler}

Dünyanın en önemli ekonomisinden biri, yüzölçümü bakımından en büyük 4. ülkesi, nüfusu ile en kalabalık ülkesi olan Çin'de tüm bölgelerde hem nitelik hem de nicelik açısından eşit eğitim firsatlarını sunmak oldukça zorlu bir iştir. Dışarıdan bakıldığında sadece doyurmanın dahi zor olduğu düşünülen nüfusuna sosyalist amaçlara hizmet eden ve yüksek kalitede eğitim vermek Eğitim Sistemi'nin temel amacıdır. Çin Eğitim Sistemi'ne her açıdan damgasını vuran düşünce sosyalizmdir. Bu temel düşünce kanunlar ve politikalarda, yönetsel yapılanmada ve eğitim programlarında kendini göstermektedir. Nitekim Eğitim Kanunu'na (1995) göre, devlet sosyalist eğitimi geliştirmek için, Marksizm-Leninizm, Mao Zedong Düşüncesi ve sosyalizmin Çin karakteriyle inşası teorilerini yol gösterici olarak korur. Sosyalizmin yanısıra eğitimde laiklik vurgulanmaktadır. Eğitim Kanunu (1995) 8. maddeye göre, devlet eğitimi dinden ayırır. Herhangi bir kurum ya da kişi dini, devletin eğitim sistemini engelleyecek biçimde kullanamaz. Eğitim yönetiminde yerel yönetim birimleriyle merkeziyetçilikten uzakmış gibi görünse de, oldukça merkeziyetçi bir yönetim anlayışı hâkimdir. Şöyle ki, merkez, eyaletler, belediyeler ve ilçeler düzeyinde eğitim yönetiminden sorumlu yapılanmalar bulunmakla beraber, Devlet Konseyi tüm bu yapıların üzerinde planlama, koordinasyon ve yönetim görevini sürdürmektedir (Eğitim Kanunu, 1995). Eğitimin devlet ideolojisine göre sürdürüldüğünü garantiye almak için ise okul yönetiminde görevlendirilen sekreterlikler mevcuttur (Bakioğlu ve Özcan, 2014).

Eğitim kurumları devlet ideolojisini yeni nesillere aktarma görevini yürütse de bir taraftan da pazar taleplerine cevap vermeleri beklenmektedir. Bu beklentilere cevaben zorunlu eğitim yaygınlaştırılmış, mesleki eğitimine ve hayat boyu öğrenmeye verilen önem artmış, yükseköğretim kalitesi arttırılmıştır. Aileler büyük oranda tek çocuk sahibi oldukları için eğitimden beklentiler yüksektir (Hu ve Szente, 2009). Okul öncesi eğitimi zorunlu değildir. Altı yaşında başlayan dokuz yıllık eğitim süresi bazı eyaletlerde $6+3$ bazı eya- 
letlerde ise $5+4$ şeklinde yapılanmıştır. Dokuz yıllık eğitimden sonra öğrenciler genel liselere, mesleki ve teknik eğitim liselerine veya üstün başarı sergileyen öğrenciler için liselere devam ederler (UNESCO, 2011). Çin'de mesleki eğitimin oldukça önemli olduğu görülmektedir. Mesleki eğitimde birçok reform gerçekleştirilmiş ve Almanya'da uygulanan mesleki eğitim sistemi örnek alınmaya çalışılmıştır (Barabash, Huang ve Lawson, 2009). Çin'de yükseköğretim sisteminde önemli reformlar yapılmaktadır. "Proje 211" çalışmasıyla Çin'deki 100 büyük üniversite ve çeşitli bölümler dünyadaki en iyi üniversite ve bölümler arasına sokmak amaçlanmaktadır (Bakioğlu ve Özcan, 2014). Özel eğitime ihtiyaç duyan bireyler için eğitim imkanlarının sınırlı olduğu görülmektedir (Kritzer, 2011). Çin'de ekonomik gelişme için bu büyük nufüsün sürekli eğitilmesi gerektiği düşünülmektedir. Bu yüzden de hayatboyu öğrenmeye önem verilmektedir (Wang ve Parker, 2014).

Çin'de sinıflarda ortalama öğrenci sayısı 37.1'dir. Bu oran öğrenci sayısının 21 olduğu OECD ortalamasının oldukça üzerindedir (OECD, 2014). Çin'de eğitim sisteminin tam bir sınav cehennemi olduğunu söylemek mümkündür. Lise giriş sınavları, lise bitirme sınavları, günlerce süren üniversiteye giriş sınavları Çin'de yaşayan bir öğrencinin alması gereken sınavlardan bazılarıdır. Dokuz yıllık temel eğitimden sonra lise giriş sınavı zorunludur. Üniversite giriş sinavı ise zorluğu ile ünlü "Gao Kao"dur (www.chinaeducenter.com). Eğitim programları defalarca gözden geçirilmiştir. Çin'de eğitim programları üzerinde eyaletlerin yetkisi olsa da, Eğitim Bakanlığı'nın belirlediği sınırların dışına çıkamazlar (UNESCO, 2011).

Eğitim hem iç hem de dış denetim araçlarıyla sıkı sıkıya denetlenmektedir. Eğitim denetimi ulusal düzeyde Devlet Eğitim Denetimi Birimi tarafından yapilır. Yerel yönetimler düzeyinde de denetim birimleri kurulmuştur (UNESCO, 2011). Eğitim denetiminde müfettişlerin geniş yetkileri bulunmaktadır (Bakioğlu ve Özcan, 2014). Öğretmen yetiştirmede eyaletler arası farklı uygulamalar mevcuttur. Ancak göreve başladıktan sonra öğretmenlerin sistematik ve sürekli bir biçimde hizmet içi eğitim almaları gerekmektedir. Öğretmenlerin lisans, yüksek lisans ya da doktora derecesini almaları teşvik edilmektedir. Öğretmenlerin performans ve kıdemlerine göre bir unvan aldığı kariyer sistemi bulunmaktadır (UNESCO, 2011). Öğretmenlerde olduğu gibi yöneticilerin de hizmet içinde ve hayat boyu kendilerini geliştirmeleri teşvik edilmekte ve beklenmektedir. Çin'de okul müdürlü olmak için uzun yıllar öğretmenlik yapmış ve başarılı bir öğretmenlik kariyerine sahip olmak 
gereklidir (www.ncee.org); ancak yeterli değildir. Okul müdürü olmak isteyenler asgari 300 saat süren eğitimler sonunda sertifika alarak göreve başlayabilirler (Yan ve Ehrich, 2009). Eğitim hem merkez hem de yerel yönetimlerin katkılarıyla finanse edilmektedir ve ailelerin eğitime yaptığı harcamalar oldukça yüksektir.

Bu çalışmada ekonomik gücüne rağmen, rejim gereği dış dünyaya uzun süre kapalı kalmış Çin Eğitim Sistemi detaylarıyla ele alınmış olsa da çalışmanın çeşitli sınırlılıkları mevcuttur. Öncelikle çalışmada yararlanılan kaynaklar İngilizce veya Türkçe dilinde, genellikle uluslararası raporlardır. Başka bir sınırlılık ise farklı eğitim politikaları olabilen eyaletlerin -örneğin Şangay- genel resim içerisinde kaybolmasıdır. Orijinal Çince kaynaklara ulaşlarak yapılacak çalışmalara ve eyalet düzeyinde incelemeler Çin Eğitim Sistemini daha iyi anlamak için yararlı olacaktır. 


\section{EXTENDED ABSTRACT}

\section{Education System in the People's Republic of China * \\ Başak Coşkun - Mustafa Çelikten \\ Sümer Science High School - Erciyes University}

In this study, it is aimed to portray the education system in China, which is of great influence on global economy (OECD, 2016) and one of the few Marxist-Leninist countries. China has been one of the oldest and most influential civilizations, nevertheless it had to cope with social riots, famine, and military defeats in the early $20^{\text {th }}$ century. After the Second World War, partly because of the autocratic socialist regime, it had been an isolated country until the 1980s (CIA, 2019). Being the fourth largest country, and the second most populated one (China ABC, 2019), China has been attracting the attentions by creating a successful profile in international exams (OECD, 2016).

In China, the main codes of education were described both in the constitution (2004) and education law (1995), both of which put great emphasis on socialist and secular principles. In Chinese constitution (2004), education is regarded both as a citizenship duty and citizenship right. In China, education is governed by central, provincial, municipal, county departments of education. Although the authority on education seems to be shared with the central and local departments, the state council has the upmost authority above all (UNESCO, 2011).

Mandatory education is nine years, with six years of primary and three years of middle school education. Preschool education, provided either in public or private schools, is not mandatory. After nine years of mandatory basic education, students have to take a national exam to attend high school. There are three types of high school as vocational, general and "key" (high performer) high schools. Vocational and technical education and life-long training have a great share in Chinese educational institutions, as China owes its industrial power to its well-trained workers (OECD, 2014). For tertiary education students have to pass maturita (end of high school exam) and take Gao Kao- university entrance exam. There is a profound competition for university education (UNESCO, 2011). China has taken big leaps in improving the quality of education in universities (Bakioğlu and Özcan, 2014). 
The schools in China is inspected closely by the "party secretary" employed in every school. The secretary follows all the programs and schools to have them obey communist party policies and rules. Apart from this constant post of party secretaries, educational supervisors have wide authorities in teachers' punishments and rewards, and guidance, as well. In order to be appointed as educational supervisor, candidates have to take exams, evaluating general knowledge and professional knowledge. After passing the tests, supervisor candidates have to work as assistant supervisor for two years (Bakioğlu and Özcan, 2014). Depending on the region they want to work, teachers are to finish two or four year bachelor's programs; yet they have to take two exams before they can be appointed as teachers. In the first three years of profession teachers work with a mentor teacher. The in-service training of teachers has great importance and teachers can have different professional titles according to their experience and performance. Teachers are supposed to attend in-service education programs on a regular basis (Hu and Szente, 2009). There are big discrepancies in teachers' salaries, depending on the region they work (www.ncee.org). In order to be a school administrator, one has to have a long and successful career as a teacher (www.ncee.org). However, being a successful teacher is not enough, there is a three-stage training program as proficiency, development and advanced education for school administration. Proficiency education, which is provided for the novice administrators, is a 300-hour program, at the end of which administrators have to write a dissertation. Development education is provided for the administrators with five years of experience. To attend the development education, one is to have the certificate of proficiency education. The last stage of educational administrators' training is advanced education. Advanced education is provided for the school administrators who exhibit exceptionally high performance (Yan and Ehrich, 2009). Education is funded together with central and provincial agencies (Huan, McCarty and Tausun, 2010).

It is clear that along with weaknesses, Education System in the People's Republic of China has many strengths. Providing quality education to each and every schools in China might be one of the most difficult challenges to overcome. Different practices in teacher training, teachers' salaries and opportunities in different states can be an obstacle to whole development in education. On the other hand, in-service training and career models for teachers, 
school administrators' continuous development can be regarded as the strengths of the system.

Besides revealing the basics of educational system in China, this study has limitations, one of which is that the data of the study was collected from English and Turkish reports, not from Chinese documents. For further research, it is suggested to use Chinese documents, which are able to give a more accurate of education in China.

\section{Kaynakça / References}

Bakioğlu, A. veÖzcan, M. (2014). Çin (Şanghay) eğitim sistemi. Ayşen Bakioğlu (Edt.) Karşılaştırmalı Ë̆̈itim Yönetimi içinde (s.1-42). Ankara: Nobel Yayıncllı.

Barabash, A., Hueng, S. ve Lawson, R. (2009). Planned policy transfer: the impact of the German model on Chinese vocational education. Compare: A Journal of Comparative and International Education, 39(1), 5-20.

CIA. (2019). The World Factbook. 27.04 .2019 tarihinde https://www.cia.gov/library/publications/the-world-factbook/geos/ch.html adresinden erişilmiştir.

China ABC (2019). 27.04.2019 tarihinde http://english.gov.cn/archive/chinaabc/ adresinden erişilmiştir.

China-Administration, Finance, and Educational Research. (t.y). 09.05.2019 tarihinde http://education.stateuniversity.com/pages/275/China-ADMINISTRATION-FINANCE-EDUCATIONAL-RESEARCH.html adresinden erişilmiştir.

China at a Glance. (2019). 27.09.2019 tarihinde http://en.people.cn/china/home.html adresinden erişilmiştir.

China Education. 09.05.2019 tarihinde http://www.chinaeducenter.com/en/cedu.php adresinden erişilmiştir.

Çin Halk Cumhuriyeti Anayasası. (2004). 29.04.2019 tarihinde http://www.npc.gov.cn/englishnpc/Constitution/node 2825.htm adresinden erişilmiştir.

Çin Halk Cumhuriyeti Eğitim Kanunu (1995). 29.05.2019 tarihinde http://www.moe.edu.cn/publicfiles/business/htm files/moe/moe_2803/200905/484 57.html adresinden erişilmiştir.

Çin Halk Cumhuriyeti Eğitim Bakanlığı-Bakan ve Üst Düzey Yetkililer (2019). 01.09.2019 tarihinde http://www.moe.edu.cn/publicfiles/business/htmlfiles/moe/moe 2796/index.html adresinden erişilmiştir. 
Çin Halk Cumhuriyeti Eğitim Bakanlı̆̆ Bölümleri (2019). 02.05.2019 tarihinde http://www.moe.edu.cn/publicfiles/business/htmlfiles/moe/moe 2796/index.html adresinden erişilmiştir.

Çin Halk Cumhuriyeti Eğitim Bakanlığı'nın Sorumlulukları (2019). 01.05.2019 tarihinde $\quad$ http://www.moe.edu.cn/publicfiles/business/htmlfiles/moe/moe 2797/200907/49988.html adresinden erişilmiştir.

Çin Halk Cumhuriyeti Ulusal İstatistik Bürosu. (2018). Çin İstatistik Yılliğı 2018. 03.05.2019 tarihinde http:/www.stats.gov.cn/tsjs/ndsj/2018/indexeh.htm adresinden erişilmiştir.

Çin Halk Cumhuriyeti'nin Siyasi Görünümü 28.04.2019 tarihinde http://www.mfa.gov.tr/cin-halk-cumhuriyeti-siyasi-gorunumu.tr.mfa adresinden erişilmiştir.

Dahlman, C., Zhihua Zeng, D. ve Wang, S. (2007). Enhancing China's competitiveness through lifelong learning. Washington, DC: World Bank.

Gao-kao National Higher Education Entrance Exam in China (2019). 08.09.2019 tarihinde http://www.chinaeducation.info/Standardised-Tests/K12Tests/gao-kao-entrance- examination.html adresinden erişilmiştir.

$\mathrm{Hu}, \mathrm{B}$. Y. ve Szente, J. (2009) Exploring the quality of early childhood education in china: implications for early childhood teacher education. Journal of Early Childhood Teacher Education, 30(3), 247-262.

Huong, L. T., McCarty, M. ve Tauson, M. (2010). Institutional and fiscal arrangements for primary and junior secondary education in China. Education sector planning and management policy series policy research report: Summary version). UNESCO Bangkok Education Policy and Reform Unit.

Jiangsu Eyaleti Eğitim Bölümü (2019). 02.05.2019 tarihinde http://english.jsjyt.gov.cn/jsed/jsedf/internal/?divflag $=3 \&$ cols $=63$ adresinden erişilmiştir.

Johnson, L., Moller, J., Jacobson, S. ve Wong, K.C. (2008). Cross-National comparisons in the international successful school principalship project: The Unites States, Norway and China. Scandinavian Journal of Educational Research, 52(4), 407-422.

Kritzer, J. B. (2011). Special education in China. Eastern Education Journal,40(1),57-63.

OECD (2016). Education in China: A snapshot. 07.01.2020 tarihinde https://www.oecd.org/china/Education- in-China-a-snapshot.pdf adresinden erişilmiştir.

OECD (2014). Education at a Glance 2014: OECD indicators. OECD Publishing. 
OECD (2011). Lessons from PISA for the United States, Strong Performers and Successful Reformers in Education. OECD Publishing.

Roberts, D. (2013, 4 Nisan). Chinese education: the truth behind the boasts. 08.05.2019 tarihinde http://www.bloomberg.com/bw/articles/2013-04-04/chinese-education-the-truth-behind-the-boasts adresinden erişilmiştir.

Shangai-China Teacher and Principal Quality. (t.y). 08.09.2019 tarihinde http://www.ncee.org/programs-affiliates/center-on-international-education-benchmarking/top-performing-countries/shanghai-china/shanghaichina-teacher-and-principal-quality/ adresinden erişilmiştir.

Şangay Eğitim Komisyonu. (t.y). 03.05.2019 tarihinden http://www.shanghai.gov.cn/shanghai/node27118/node27386/node27400/node 27838/userobject22ai38994.html adresinden erişilmiştir.

The Economist Intelligence Unit (2019). China. 28.04.2019 tarihinde http://country.eiu.com/china adresinden erişilmiştir.

T.C. Ekonomi Bakanlığı (2013). Çin Halk Cumhuriyeti ülke raporu. 28.04.2019 tarihinde http://www.tucsiad.org.tr/Images/FileManager/2012 2013\%20\%C3\%87in\%20\%C3\%9Clke\%20Raporu.pdfadresinden erişilmiştir.

UNESCO. (2011). World data on education (7th Edition). (IBE/2011/CP/WDE/II) Geneva: UNESCO/International Bureau of Education.

Wang, V.C.X., ve Parker, J. (2014). Lifelong learning in China. Revista Internacional de Organizaciones, 12, 71-88.

World Bank(2019) Çin ülke profili. 30.09.2019 tarihinde http://www.worldbank.org/en/country/china/overview adresinden erişilmiştir.

Yan, W. ve Ehrich, L. C. (2009). Principal Preparation and Training: A look at china and its issues. International Journal of Educational Management, 23(1), 51-64.

Zhongkao- Senior High School Entrance Examination in China (2015). 08.05.2019 tarihinde http://www.chinaeducation.info/Standardised-Tests/K12sts/zhong-kao-examination.html adresinden erişilmiştir.

\section{Kaynakça Bilgisi / Citation Information}

Coşkun, B. ve Çelikten, M. (2020). Çin Halk Cumhuriyeti eğitim sistemi. OPUS-Uluslararası Toplum Araştırmaları Dergisi, 15(24), 2982-3011. DOI: $10.26466 /$ opus. 669104 